\title{
En Planteleverance fra 1586 til Hansborg i Haderslev.
}

Blandt de bedste Kilder til Forstaaelse af ældre Tiders Haver, deres Indretning og især deres Indhold har vi Fortegnelserne over Planter, saaledes som de har været formet enten som utrykte Rekvisitioner, Regninger over Leverancer, Fortegnelse over Planter til Lxgedomsbrug, eller Fortegnelse over dyrkede Planter o. s. fr. Da Lægeboger og tilitels Urtebøger for Havefolk ikke blot nævner saadanne Planter, som dyrkes hos os, men ogsaa medtager saadanne, som man kunde ønske dyrket, og som derfor anbefales til Dyrkning, eller som man kan forskaffe sig fra Udlandet, er de ikke helt troværdige med Hensyn til Bedømmelsen af, hvad der paa den paagældende Tid virkelig har vokset i Haverne; de bringer sikkert Navne paa adskillige Planter, som ikke kan forudsættes at vare bleven dyrket. Mere paalidelige i saa Henseende er Fortegnelser over Planter i ganske hestemte Haver eller de nævite Rekvisitioner og Regninger.

Den ældste af Forf. kendte (og i dansk Litteratur omtalte) Fortegnelse over voksende Planter er sikkert den, der angaar Planterne i Lave Steffensens Have i Ribe (154-54), og man træffer her paa en som det synes efter Datidens Forhold endog meget righoldig Plantesamling.") Fra den følgende Tid foreligger der Registre over Handelsvarer, Toldforordninger etc. som oplyser et og andet om, hvad man handlede med og forbrugte, nærmest af Planteprodukter, og forst fra 1569 foreligger vistnok den næste Liste over betydelige Planteindkøb, nemlig angaaende det, Kong Fr. II. skulde bruge for at indrette sin Have ved Skanderborg Slot. $\left.{ }^{2}\right)$ Mens den forstnavnte Liste narmest omfattede Urter og Stauder, beretter den her nævnte om Træer og Buske, af hvilke dog enkelte næppe kan forudsættes at have kunnet trives i Skanderborg, selv ikke i en kongelig Have.3) 
Til denne Have er yderligere i Aarene 1581-82 og kort efter 16-Tallets Begyndelse købt Urter og Stauder.")

For Sønderjyllands Vedkommende har der til dette Tidsrum ikke hidtil foreligget Beretning om noget Planteindkøb, og i en af mine tidligere Artikler herom er der kun antydningsvis berettet noget herom. $\left.{ }^{5}\right)$ Der kunde derfor være Anledning til at drage den Liste over Levering af Planter til $\mathrm{Hans}$ borg, som kendes fra Aaret 1586, frem i Lyset for derved at skaffe et mere konkret Bidrag til Forstaaelse af, hvad der voksede i den gamle Slotshave, specielt sammenlignet med, hvad der kendes andetsteds fra paa denne Tid.

Fortegnelsen over disse Planter findes i Rigsarkivet i København. Den findes $i$ de saakaldte "Mathiesens Samlinger" i en "Pakke 18, Hansborg Slot«. Denne Samling er i sin Tid afleveret til Tyskland, men der er foretaget en Afskrift af Dokumenterne. Fortegnelsen er betitlet "Catalogus seminum et plantarum og er dateret 26. August 1586. Den er udfærdiget i Anledning af, at Kong Fr. II. havde skrevet til Landgreve Wilhelm af Hessen om nogle Planter, og han modtog da gennem sin i dette Øjemed udsendte Gartner, hvis Navn vi ikke kender, 52 Slags Planter (eller Frø af saadanne?). Desværre er Navnene paa de anforte Planter i flere Tilfolde temmelig uforstaaelige; men der er dog iblandt Planterne adskillige Kendinge, og flere, som vistnok her næunes dyrket for forste Gang indenfor Rigets Græuser.") Nedenfor anføres Listen, saaledes som den fremtræder $i$ sin Afskrift, og i Parenthes er tilfojet den Forklaring, som kan gives, $\left.{ }^{6}\right)$, ligesom det med et $R$ er betegnet, om Navnet ogsaa forekommer i den forannævnte Fortegnelse fra Ribe, mens $S$ betegner, at den forekommer i Forbindelse med Skanderborg Slotshave.

\section{„Seminum catalogus" :}

abutilon

alisson dodonej (?)

aquilegia varia (Akkeleje; R.)

anemine tertia (Anemone?)

argentina (Røllike) 
('ochlearia (maaske C. officinalis Kokleare)

Daucu oreticus (Gulerod? S.?)

Dictamnus (D. albus)

Digitalis (D. purpurea; Fingerbnlle)

ferrum equinum (Hispoclepis?)

foeniculum romanum (Fennil)

foenum grecum (Triganella foenum græcum, Bukkehorn)

halicacalus peregri(n)um

helleborus niger (Julerose; R.)

inperatoria (Imperatoria ostrutium, Mesterurt)

lupini lutei (Lupin; Lupinus luteus; R.)

lupini cærulei (L. angustifol. ?; R.)

lunaria (L. biennis, Maanerude?)

medica arabica

medica minima

mellilotus hispanica (Stenkløver?)

menta hispanica (Mynte?)

mentraftrum tuberosum

mirris maior (Myrrhis odorata? Sødskærm)

papauer multiplex (Valmue; Papaver somiferum fl. pl.? R.)

planta indica

piretrum (Pyretrum? Chrysanthemum parthenicum?)

poma aethiopica

rabarbarum armericum.(Rhabarber?)

seseli aethiopicum

- massiliense

sorgo

stocras (Stoechas?)

valeriana greca (Valeriana, Baldrian)

viola mariana (Campanula medicum, Klokkeblomst)

virga aurea (Solidago virga aurea)

talictrum album

flaspi percane

luteum

tusai (Kejserkrone?)

\section{Plantarum catalogus.}

Anemone (R.)

anthemis sine camomillis mulltiplex (dobbelt Pyretrum roseum? dobb. Chrysanthem. parthen.)

calamus aromaticus (Kalmus: Acorus calamus)

cederu (Ceder? Cedrus libani?)

hiacinticus orientalis (Hyacint; R.) 
iris bulbosa (Iris anglica, R.)

iris florentine alba (Violrod; R.)

- illirica

narcissus luteus oderatus (Paaskelilje? R.)

tulipa lutea (Tulipan; Tulipa silvestris) R.)

- rueba

tusai (Kejserkrone?)

Det bemærkes, at naar der er anført $R$. ved de ovenstaaende Planter, betyder det ikke, at just samme Species er opført i Ribe, men at i hvert Fald Slægtsnavnet er det. Det ses, at kun angaaende 1 Planteart kan der være Tale om, at den er med i Skanderborg-Fortegnelsen, og det er endda tvivlsomt. Denne Fortegnelse rummer ikke som ovenstaaende fra Hansborg praktisk talt kun Prydplanter eller medicinske Planter (Krydderurter o. I.), men den rummer for Aarene 1581/82 og Beg. af 16-Tallet væsentligt kun Nytteplanter saasom Løg, Persille, Rødheller samt Krydderurter. Kalder man alle de i HansborgFortegnelsen opforte Planter for Prydplanter, hvilket de maa betegnes som efter den Ordre, Kongen udstedte, rummer den dog med sine 52 Numre ikke nær saa mange Navne som RibeFortegnelsen, der indeholder 245 Plantearter, hvoraf alene 70 kan kaldes Prydplanter.

Denne Plantefortegnelse forstærker det Indtryk, man kan have af Haven ved Hansborg, at det har været en udpræget Prydhave. Mens Kong Fr. II fyldte Skanderborg-Haven med nyttige Vækster: Frugttræer og rare Køkkenurter, plantede han kun Krydderurter eller Blomsterplanter ind $i$ sin Have ved Hansborg; og mens det i Skanderborg blot var Tolderen, der skulde skaffe de forønskede Træer, sendte han fra Hansborg sin egen Gartner afsted for at hente en udsøgt Samling af Frø og Planter fra en Mand, der var velkendt for sin smukke Lysthave og rige Plantesamling. Der er kælet for Haven ved Hansborg, ikke alene med Planter, men ogsaa med Lysthus, Badstue, Pilkentavl og deslige Ting. Ikke for intet er Lysthaven kaldt "Kräutergarten«; de 52 Urter har gjort, at den svarede til sit Navn. 
I Tilslutning til den her omhandlede Fortegnelse skal endelig erindres, at der for sønderjydske Forhold ogsaa foreligger Plantefortegnelser fra Aarene 1649 og 1679, hvorom her ikke nærmere skal berettes, idet disse allerede er trykt.7)

Johannes Tholle.

Noter.

1) Iflg. Afskrift fra et Dokument ang. Lave Steffensens Have i Ribe, (1544-54); Stephan Nyelands efterl. Manuskript, Landbohøjsk. Bibl.

${ }^{2}$ ) Cancelliets Brevbøger, 30/9. 1569; sammenlign Forf.s Artikel i "Aarbøger udg. for Aarhus Stift" 1926.

$\left.{ }^{3}\right)$ Bruunio og Lange: Danm. Havebrug og Gartneri til 1919.

-) Fra Arkiv og Musæum III 560-61.

5) Sønderjydske Aarboger 1927 S. 173-74.

-) Forklaringen til Navnene er for de flestes Vedkommende velvilligst givet af Botanisk Haves Gartner, Hr. Axel Lange, 15./8. 1930.

7) Schriften des Naturwissenschaftichen Vereins f. Schlesw.Holst. 1892 S. 1 ff: Zwei ältere Dokumente zur Geschichte des Gartenbaus in Schl.-Holst. 